\title{
Absence of Somatic Histone H1 in Oocytes and Preblastula Embryos of Xenopus laevis
}

\author{
Robert Hock, ${ }^{*}$ Antoon Moorman, $†$ Dagmar Fischer, ${ }^{*}$ AND Ulrich Scheer* \\ *Department of Cell and Developmental Biology, Theodor-Boveri-Institute (Biocenter), University of Würzburg, Am Hubland, D-8700 Würzburg, \\ Germany; and †Department of Anatomy and Embryology, University of Amsterdam, Meibergdreef 15, 1105 AZ Amsterdam, The Netherlands
}

Accepted March 8, 1993

Available data on the occurrence and expression of somatic histone $\mathrm{H} 1$ during oogenesis and early embryogenesis of Xenopus laevis are contradictory. In particular the reported presence of a large storage pool of histone H1A in oocytes is difficult to reconcile with the high transcriptional activity of all gene classes in this specific cell type. In the present study we have used polyclonal antibodies raised against somatic Xenopus histone H1 (H1A and H1A/B) for combined immunoblotting experiments to quantitate H1 pools and immunolocalization studies to visualize chromosome-bound H1. Both approaches failed to detect soluble or chromosomal histone $\mathrm{H} 1$ in vitellogenic oocytes, eggs, and cleavage-stage embryos up to early blastula. In addition, chromatin assembled in Xenopus egg extract was also negative for histone $\mathrm{H} 1$ as revealed by immunofluorescence microscopy. Lampbrush chromosomes not only lacked histone H1 but also the previously identified histone H1-like B4 protein (Smith et al., 1988, Genes Dev. 2, 1284-1295). In contrast, chromosomes of eggs and early embryos fluoresced brightly with anti-B4 antibodies. Our results lend further support to the view that histone $\mathrm{H} 1$ expression is developmentally regulated during Xenopus oogenesis and embryogenesis similar to what is known from other species. () 1993 Academic Press, Inc.

\section{INTRODUCTION}

The Xenopus egg contains large stockpiles of components required for the initial stages of embryogenesis, including a pool of non-chromatin-bound histones. Owing to this prefabricated maternal material which is stored in a disassembled mitotic form, extract prepared from activated Xenopus laevis eggs is capable of assembling exogenous protein-free DNA into chromatin and, beyond that, into nuclear-like structures (Newmeyer et al., 1986; Newport, 1987; for review see Dilworth and Dingwall, 1988; Laskey and Leno, 1990). Direct measurements revealed a storage pool of $140 \mathrm{ng}$ of total histones per $X$. laevis egg, an amount that would be sufficient to assemble the chromatin of the 20,000 nuclei of a late blastula (Woodland and Adamson, 1977). Data concerning the existence of a soluble pool of histone $\mathrm{H} 1$ in Xenopus oocytes or eggs are, however, controversial. Based on immunoblotting data, van Dongen et al. (1983) reported that mature oocytes contain a maternal histone $\mathrm{H} 1 \mathrm{~A}$ pool of at least $8-10 \mathrm{ng}$. $\mathrm{H} 1 \mathrm{~A}$ is the predominant histone $\mathrm{H} 1$ subtype in embryonic and adult tissues of Xenopus (Destrée et al., 1973; Flynn and Woodland, 1980; Risley and Eckhardt, 1981). Using immunofluorescence microscopy Newport (1987) found that histone H1 is present in chromatin assembled in Xenopus egg extract. In contrast, biochemical analyses failed to reveal the presence of histone $\mathrm{H} 1$ in chromatin assembled in egg (Dilworth et al., 1987) and oocyte extract (Shimamura et al., 1988). Only when histone $\mathrm{H} 1$ was added to the assembly mixture did exogeneous $\mathrm{H} 1$ become incorporated into the minichromosomes (Rodriguez-Campos et al., 1989; Shimamura et al., 1989). "Natural" chromatin isolated from early Xenopus cleavage-stage embryos was also shown to be deficient in histone H1 (Wolffe, 1989, 1991; Ohsumi and Katagiri, 1991).

The presence of a large storage pool of histone $\mathrm{H} 1$ in growing Xenopus oocyte would be difficult to reconcile with the known properties of this protein. Numerous studies support the view that $\mathrm{H} 1$ is a potent general repressor of gene activity (e.g., Laybourn and Kadonaga, 1991) and plays an essential role in the formation of higher order structures characteristic of condensed, i.e., transcriptionally inactive chromatin (Renz et al., 1977; Thoma et al., 1979; for further references see van Holde, 1989). Direct evidence supporting this notion comes from microinjection experiments performed on cultured rat myoblasts. Upon injection of purified histone H1 (a mixture of H1A and H1B) into these cells transcription was inhibited in a concentration-dependent manner and nuclear chromatin became highly condensed (Bergman et al., 1988). These inhibitory effects were observed upon introduction of approximately $15 \times 10^{6}$ exogenous H1 molecules per cell. Assuming a pool size of $10 \mathrm{ng}$, the 


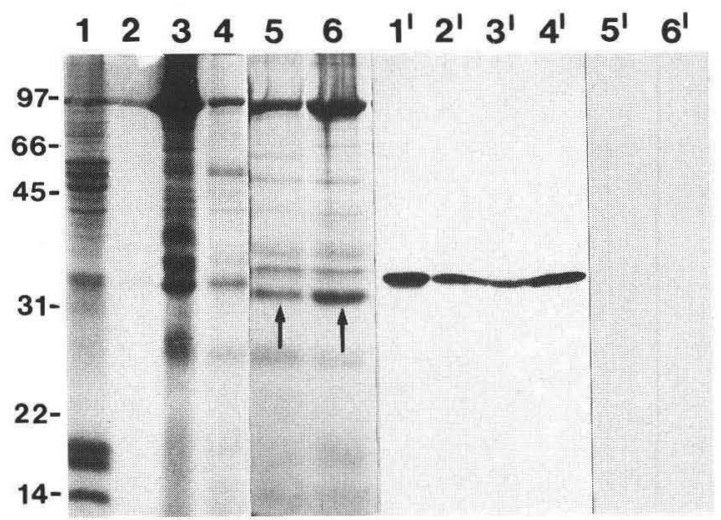

Fig. 1. Analysis of histone H1 in Xenopus somatic cells and oocytes by immunoblotting. (Lanes 1-6) Various protein fractions were resolved by SDS-PAGE and stained with Coomassie blue. (Lane 1) Total proteins of $1 \times 10^{6}$ XLKE-A6 cell nuclei; (lane 2) proteins extracted with $5 \%$ PCA from $1 \times 10^{6} \mathrm{~A} 6$ cell nuclei; (lane 3 ) total proteins of 2.5 mg ovarian tissue; (lane 4) proteins extracted with 5\% PCA from 10 $\mathrm{mg}$ ovarian tissue; (lane 5) proteins extracted with $5 \%$ PCA from 50 manually defolliculated stage IV oocytes; (lane 6) proteins extracted with 5\% PCA from 50 manually defolliculated stage VI oocytes. Molecular weights of the protein standards are indicated in $\mathrm{kDa}$. (Lanes $1^{\prime}-6^{\prime}$ ) In the corresponding immunoblot histone $\mathrm{H} 1$ is identified exclusively in the samples containing somatic cells (lanes $1^{\prime}-4^{\prime}$ ) but not in isolated oocytes (lanes $5^{\prime}$ and $6^{\prime}$ ). The prominent protein bands which run slightly ahead of histone $\mathrm{H} 1$ (denoted by arrows in lanes 5 and 6 ) represent nucleoplasmin.

number of H1 molecules stored in a single Xenopus oocyte exceeds this value by 4 magnitudes $\left(27 \times 10^{10} \mathrm{H} 1 \mathrm{~A}\right.$ molecules per oocyte) and yet the lampbrush chromosomes and amplified nucleoli are transcriptionally extremely active (reviewed in Scheer and Dabauvalle, 1985; Davidson, 1986). Likewise, oocyte 5S RNA genes and satellite I DNA which are known to be transcribed at high levels in Xenopus oocytes by RNA polymerase III are repressed in vitro by addition of histone H1 (Schlissel and Brown, 1984; Wolffe, 1989). In this context it is worth mentioning that, since accumulation of $\mathrm{H} 1$ was found to be an early event in oogenesis (van Dongen et al., 1983), an excess amount of non-chromatin bound H1 should be present throughout the lampbrush chromosome stage of oocyte growth.

Biochemical analyses of chromatin isolated from early Xenopus cleavage stage-embryos up to midblastula or gastrula failed to detect histone H1 (Wolffe, 1989, 1991; Ohsumi and Katagiri, 1991). Comparable studies with Xenopus egg chromosomes or oocyte lampbrush chromosomes have not been carried out. Since these chromosomes cannot be isolated in sufficient yield and purity necessary for biochemical investigations, we employed immunofluorescence microscopy to address the question of whether they contain histone H1. This method is highly sensitive and allows, for instance, the detection of core histones along the axis of the lampbrush chromosomes (e.g., Scheer and Dabauvalle, 1985). Since small amounts of histone H1 might have escaped detection in the above-mentioned biochemical studies, we extended our immunocytochemical investigations also to embryonic chromatin. In addition, we reexamined the controversial issue of the presence or absence of a histone H1 pool in Xenopus oocytes, eggs, and early embryos by immunoblotting experiments.

\section{MATERIALS AND METHODS}

\section{Biological Materials and Cell Fractionation}

Adult $X$. laevis were purchased from the South African Snake Farm (Fish Hoek, Cape Province, South Africa). Eggs were obtained from hormone (human chorionic gonadotropin)-stimulated females and fertilized in vitro (Wolf and Hedrik, 1971). When the embryos had reached the appropriate developmental stage (defined according to Nieuwkoop and Faber, 1975), their jelly coat was removed with a $2 \%$ cysteine solution adjusted with $\mathrm{NaOH}$ to $\mathrm{pH} 7.8$.

Pieces of ovary were obtained from anesthetized animals and placed in modified Barth's medium (Peng, 1991). Oocytes were defolliculated by pretreatment with $0.2 \%$ collagenase (Boehringer Mannheim, Germany) in $87 \mathrm{~m} M \mathrm{NaCl}, 2.5 \mathrm{~m} M \mathrm{KCl}, 1 \mathrm{~m} M \mathrm{MgCl}_{2}, 1 \mathrm{mM} \mathrm{Na} \mathrm{HPO}_{4}$, $0.012 \mathrm{~m} M$ polyvinylpyrrolidone (PVP 40; Sigma, Deisenhofen, Germany), $5 \mathrm{mM}$ Hepes ( $\mathrm{pH} 7.8$ ) for $2 \mathrm{hr}$ at $37^{\circ} \mathrm{C}$ and subsequent manual removal of remaining follicle epithelium under a dissecting microscope. The oocytes were then staged according to Dumont (1972) and processed for PCA extraction and/or SDS-PAGE.

Lampbrush chromosomes were prepared essentially as described by Gall et al. (1981). Chromosome preparations were kept in $70 \%$ ethanol at $4{ }^{\circ} \mathrm{C}$ until use.

Cultured cells derived from $X$. laevis kidney epithelium (XLKE cells, line A6; American Type Culture Collection) were grown as described (Smith and Tata, 1991). Nuclei were isolated according to Krohne et al. (1981).

\section{Antibodies}

The rabbit antibodies directed against Xenopus histone H1A or both subtypes H1A and H1B (anti-H1A/B) have been described (Moorman et al., 1984; Moorman and de Boer, 1985). Rabbit antibodies to B4 protein, an H1-like protein expressed during early Xenopus development, have also been characterized in detail (Smith et al. 1988). The mAb GA199 (IgG2b) is a broadly reacting histone antibody which recognizes the core histones as 

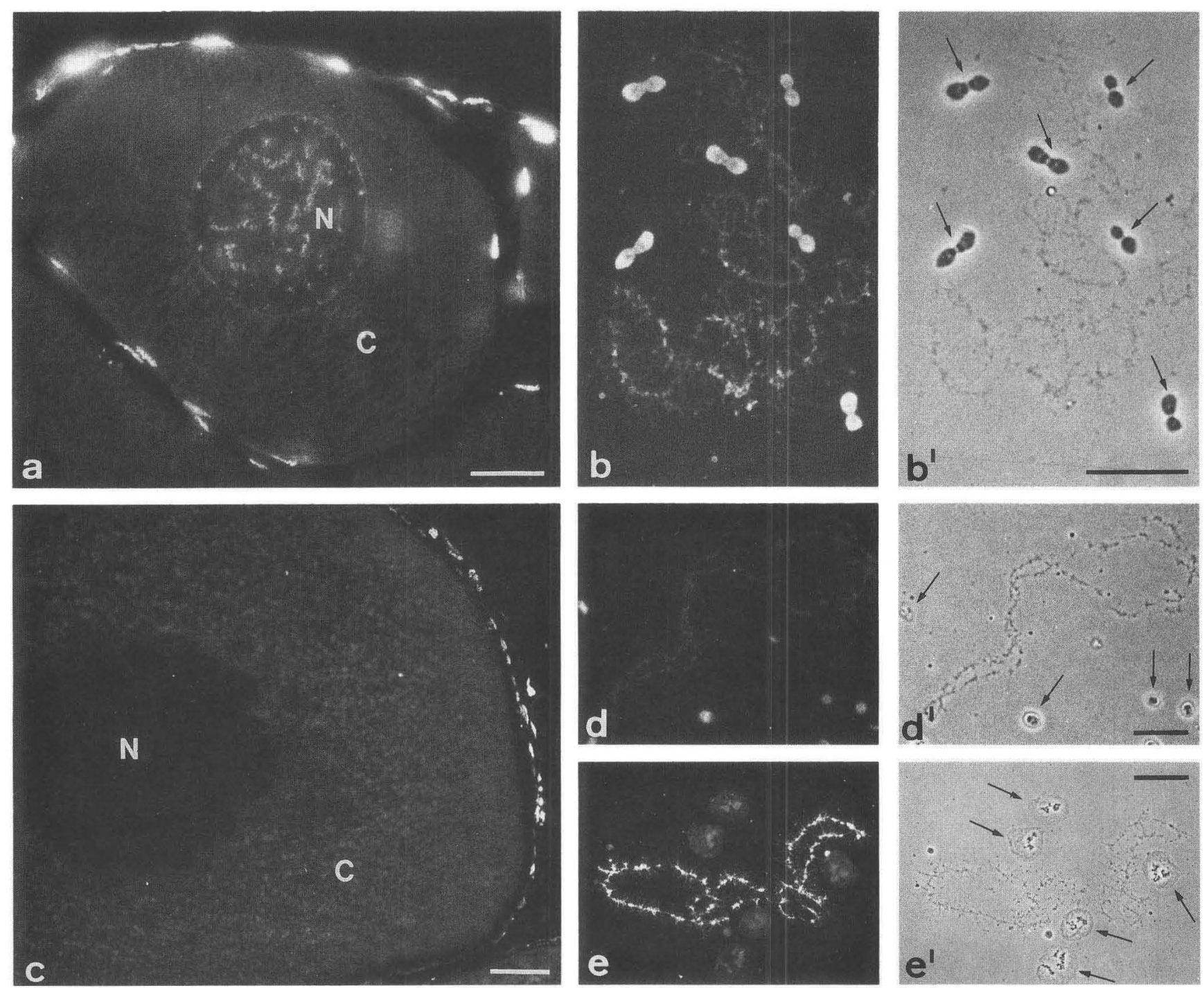

FIG. 2. Immunofluorescence microscopy of paraffin sections of freeze-substituted Xenopus oocytes (a, previtellogenic stage II oocyte; c, midsized stage IV oocyte) and isolated lampbrush chromosomes (b-e) with antibodies against histone H1 (a-d) and, as positive control, mAb GA199 (e). Lampbrush chromosomes were isolated from either stage II (b, $\left.\mathrm{b}^{\prime}\right)$ or stage IV (d, $\left.\mathrm{d}^{\prime} ; \mathrm{e}, \mathrm{e}^{\prime}\right)$ oocytes. Phase-contrast images are shown $\left(b^{\prime}, d^{\prime}, e^{\prime}\right)$. Histone H1 is clearly present in the nuclei of follicle cells surrounding the oocytes (a, c). Only lampbrush chromosomes of previtellogenic oocytes are stained with anti-H1, both in situ (a) and after isolation (b). In contrast, lampbrush chromosomes of vitellogenic (stage IV) oocytes are completely negative (c,d). In nuclear spread preparations of stage II oocytes the dumbbell-shaped amplified nucleoli (indicated by arrows in $b^{\prime}$ ) react strongly with anti-H1 (b). Nucleolar remnant structures of stage IV oocytes (arrows in $\mathrm{d}^{\prime}$ ) reveal only a faint fluorescence (d). In control preparations mAb GA199 stains the axes of the lampbrush chromosomes (e). Amplified nucleoli are denoted by arrows in the corresponding phase image (e'). N, nucleus; C, cytoplasm. Bars (a, b', d', e $\left.e^{\prime}\right), 25 \mu \mathrm{m}$; (c) $50 \mu \mathrm{m}$.

well as histone $\mathrm{H} 1$ of a wide variety of species including Xenopus (Platz, 1991).

\section{Nuclear Assembly in Egg Extract}

Nuclei were reconstituted from bacteriophage lambda DNA (Gibco-BRL; Eggenstein, Germany) added to Xenopus egg extract essentially as described (Newport, 1987). After an incubation time of $90 \mathrm{~min}$ at $22^{\circ} \mathrm{C}$ the newly assembled nuclei were processed for immunofluo- rescence microscopy (Dabauvalle et al., 1991). Stability of histone $\mathrm{H} 1$ was determined by addition of exogenous $\mathrm{H} 1$ to the egg extract and incubation for various times followed by immunoblot analysis.

\section{PCA Extraction}

Isolated nuclei of XLKE-A6 cells, defolliculated oocytes, and dejellied eggs were extracted with $5 \%$ PCA as described by Nicolas and Goodwin (1982). Solubilized 

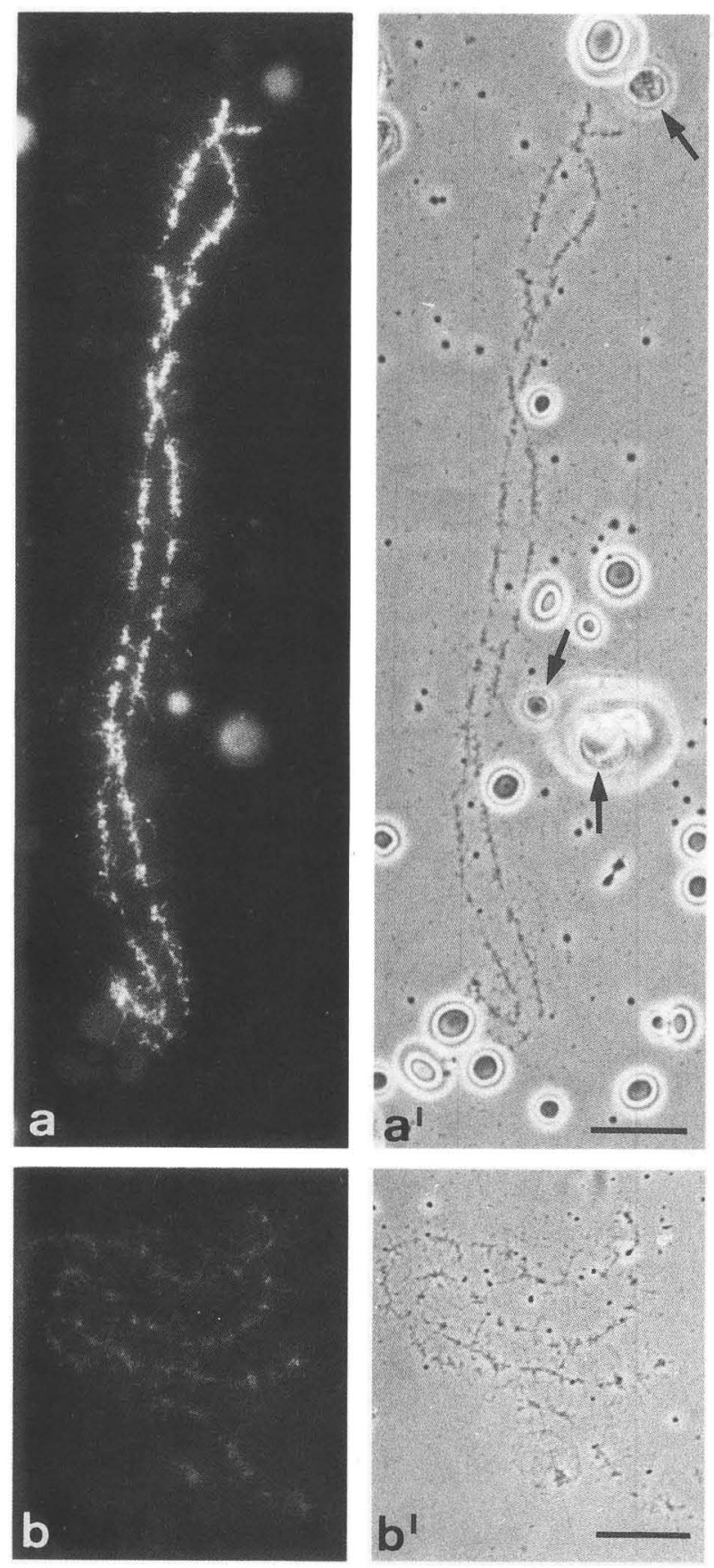

FIG. 3. Exogenous histone H1 binds to lampbrush chromosomes of Xenopus oocytes. Oocytes were injected into the cytoplasm with $50 \mathrm{ng}$ H1 prepared from XLKE-A6 cells $\left(\mathrm{a}, \mathrm{a}^{\prime}\right)$ or, as control, with the same amount of BSA $\left(b, b^{\prime}\right)$. Two hours later the lampbrush chromosomes were isolated and processed for immunofluorescence microscopy using anti-H1 antibodies (a,b). Injected $\mathrm{H} 1$ is seen to be associated with the chromosome axes and the amplified nucleoli (a). The arrows in the corresponding phase-contrast picture $\left(\mathrm{a}^{\prime}\right)$ denote extrachromosomal nucleoli; the other spherical objects in this preparation are yolk granules. Note that the lateral loops of the chromsomes are largely retracted $\left(a^{\prime}\right)$ in contrast to the control preparation $\left(b^{\prime}\right)$. Bars, $20 \mu \mathrm{m}$.

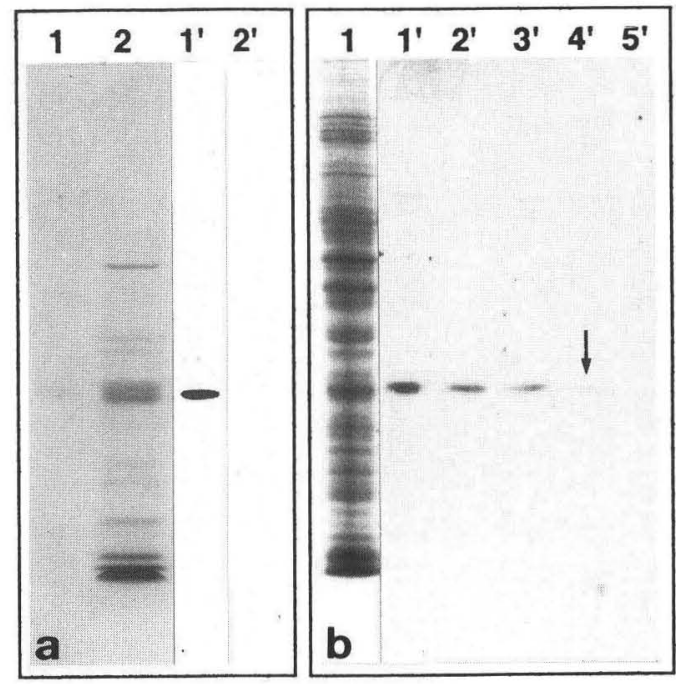

FIG. 4. H1 is not detectable in eggs by immunoblotting. (a) PCA-soluble proteins from 120 Xenopus eggs (lane 2) and, as positive control, somatic XLKE-A6 cell nuclei (lane 1) were resolved by SDS-PAGE and stained with Coomassie blue. PCA extract from 320 eggs was applied to the corresponding gel used for the immunoblot with anti$\mathrm{H} 1$ (lane $2^{\prime}$ ). Histone $\mathrm{H} 1$ is detected in the somatic nuclei (lane $1^{\prime}$ ) but not in the eggs (lane $2^{\prime}$ ). The prominent protein present in the egg PCA extract which almost comigrates with $\mathrm{H} 1$ (lane 2) is nucleoplasmin. (b) Quantitation of the detection limit of histone H1 by immunoblotting. Various amounts of histone $\mathrm{H} 1$ extracted from cultured Xenopus cells were added to aliquots of egg extract (equivalent to eight eggs each). After an incubation time of $20 \mathrm{~min}$ at room temperature the proteins were resolved by SDS-PAGE and either stained with Coomassie blue (lane 1) or analyzed by immunoblotting with anti-H1 (lanes $1^{\prime}-5^{\prime}$ ). The following amounts of $\mathrm{H} 1$ were added: $44 \mathrm{ng}$ (lanes $1,1^{\prime}$ ), $36 \mathrm{ng}$ (lane $2^{\prime}$ ), $28 \mathrm{ng}$ (lane $3^{\prime}$ ), $20 \mathrm{ng}$ (lane $4^{\prime}$ ), and no addition of $\mathrm{H} 1$ (lane $5^{\prime}$ ). As little as $20 \mathrm{ng} \mathrm{H1}$ is detectable (arrow in lane $4^{\prime}$ ).

proteins were precipitated by addition of 6 vol of acetone for $2 \mathrm{hr}$ at $-20^{\circ} \mathrm{C}$.

\section{Gel Electrophoresis and Immunoblotting}

Proteins were resolved by SDS-PAGE (Laemmli, 1970) using $13 \%$ acrylamide in the separating gel. For immunoblots, proteins were transferred to nitrocellulose (Kyhse-Andersen, 1984). The membrane was blocked with $10 \%$ nonfat dry milk in TBS and incubated with anti-H1 antisera diluted 1:500 in blocking buffer for 45 min. After several washes in TBST (TBS $+0.1 \%$ Tween), secondary antibodies (goat anti-rabbit IgG conjugated with peroxidase; Medac, Hamburg, Germany) were added at a 1:1000 dilution in the blocking buffer for $45 \mathrm{~min}$. After several wash steps, bound antibodies were visualized using the enhanced chemical luminescence detection system (ECL; Amersham Buchler, Braunschweig, Germany).

\section{Freeze Substitution and Paraffin Embedding}

Small pieces of ovary, dejellied eggs, and embryos were shock-frozen in isopentane cooled in liquid nitro- 

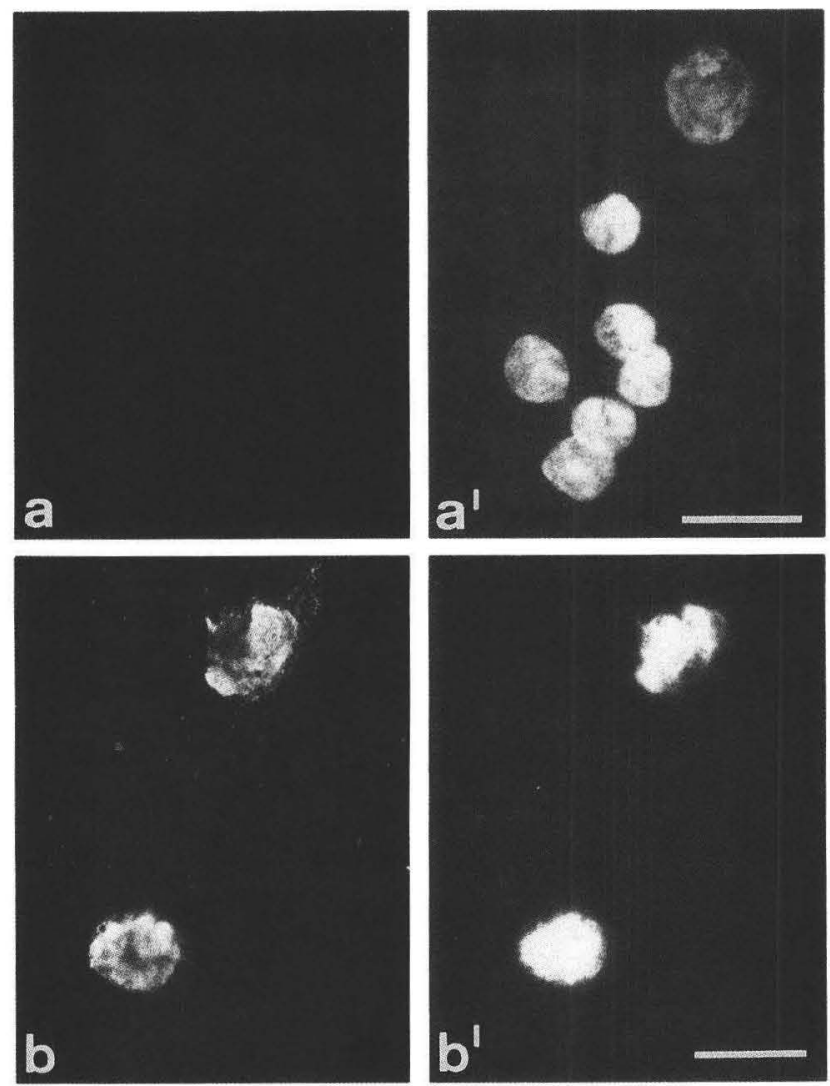

FIG. 5. Immunofluorescence microscopy of nuclei assembled from bacteriophage $\lambda$ DNA in Xenopus egg extract. Nuclei were spun on microscope slides, fixed with acetone, and incubated with anti-H1 (a) or mAb GA199 (b). The corresponding Hoechst fluorescence is shown in the right panel $\left(a^{\prime}, b^{\prime}\right)$. H1 is not detectable in the in vitro nuclei (a). Bar, $20 \mu \mathrm{m}$.

gen followed by freeze-substitution in a 6:3:1 mixture of methanol, chloroform, and acetic acid (methacarn) for 20 days at $-40^{\circ} \mathrm{C}$ (CS-auto-freezer; Reichert-Jung, Nussloch, Germany) as described by Moorman and de Boer (1985). Alternatively, freeze-substitution was also performed in ethanol at $-70^{\circ} \mathrm{C}$ for 5 days with two changes of the ethanol after $1 \mathrm{hr}$ and 1 day, respectively. Freeze-substituted material was then brought to room temperature, transferred into tertiary butanol for $1 \mathrm{hr}$ at $40^{\circ} \mathrm{C}$, and finally embedded in Histosec (Merck, Darmstadt, Germany), using standard procedures.

\section{Immunofluorescence Microscopy}

In vitro assembled nuclei were centrifuged onto microscope slides, fixed in acetone for $10 \mathrm{~min}$ at $-20^{\circ} \mathrm{C}$, and air-dried (see Dabauvalle et al., 1991). Lampbrush chromosome preparations were transferred from $70 \%$ ethanol into PBS without air-drying. Paraffin sections (8 $\mu \mathrm{m}$ ) of ovaries, eggs, and embryos were deparaffinated in xylene, rehydrated by a descending alcohol series, and finally placed in PBS. Then they were incubated in $3 \%$ BSA in PBS for 30 min at $4^{\circ} \mathrm{C}$ and washed several times prior to use.

The specimens were then incubated for $30 \mathrm{~min}$ at room temperature with the primary antibodies (anti-H1 serum diluted 1:100; anti-B4 serum diluted 1:100; undiluted supernatant of the GA199 hybridoma cells) except for the paraffin sections, which were incubated for $2 \mathrm{hr}$ at room temperature or overnight at $4^{\circ} \mathrm{C}$. Following three wash steps in PBS (5 min each), appropriate FITC-conjugated secondary antibodies (Dianova, Hamburg, Germany; diluted 1:50 in PBS) were added for another $30 \mathrm{~min}$ or, in the case of the paraffin sections, $1 \mathrm{hr}$. Specimens were then counterstained with Hoechst $33258(5 \mu \mathrm{g} / \mathrm{ml})$, washed three times as described above, and mounted in Mowiol.

All photographs were taken with a Zeiss Axiophot equipped with epifluorescence optics and the appropriate filter sets (Zeiss Oberkochen, Germany).

\section{Oocyte Injection}

PCA-soluble proteins of XLKE-A6 cell nuclei were recovered by acetone precipitation. The pellet was washed two times with acidified acetone and once with $70 \%$ acetone and finally dissolved in water at a concentration of $1 \mathrm{mg} / \mathrm{ml}$. Histone $\mathrm{H} 1$ was highly enriched as monitored by SDS-PAGE. The amount of $\mathrm{H} 1$ was determined by scanning the Coomassie blue-stained gels at $560 \mathrm{~nm}$ in a Gilford model 2600 spectrophotometer equipped with a linear transport device. Calf thymus H1 (Sigma) served as an internal standard.

Manually defolliculated stage IV oocytes were injected into the cytoplasm at approximately $50 \mathrm{nl}$ each. Lampbrush chromosomes were prepared $2 \mathrm{hr}$ later and processed for immunofluorescence as described above.

\section{RESULTS}

Among the three histone $\mathrm{H} 1$ variants found in embryonic and adult tissues of $X$. laevis, H1A is the most abundant (Destrée et al., 1973; Flynn and Woodland, 1980; Risley and Eckhardt, 1981) and has also been reported to occur in a stored form in the oocytes (van Dongen et al., 1983). In the present study we have used polyclonal antibodies directed against Xenopus H1A or both variants H1A and H1B (anti-H1A/B) for quantitative analyses of histone $\mathrm{H} 1$ in oocytes, eggs, and early embryos by immunoblotting experiments and for cytological detection of chromosome-bound $\mathrm{H} 1$ by immunofluorescence microscopy (for a detailed characterization of the antibodies see Moorman et al., 1984; Moorman and de Boer, 1985). Both antibodies produced essentially identical results and will therefore be referred to as anti-H1. In addition, we also used the mAb GA199 which reacts 
with the major H1 subtypes of somatic cells as well as the core histones.

\section{Histone H1 Is Detected in Ovarian Tissue but Not in Oocytes}

In immunoblots the polyclonal anti-H1 antibodies stained specifically histone $\mathrm{H} 1$ of nuclei isolated from cultured XLKE-A6 cells (Fig. 1, lane 1') and of total ovarian tissue (Fig. 1, lane $3^{\prime}$ ). In order to allow the analysis of large amounts of biological material by PAGE, we first solubilized histone H1 by extraction of XLKEA6 cell nuclei and total ovarian tissue with 5\% PCA, followed by SDS-PAGE and immunoblotting. As illustrated in Fig. 1, H1 could be recovered with this procedure in high yields in an immunoreactive form (compare the intensities of the $\mathrm{H} 1$ signals in lanes $1^{\prime}$ and $2^{\prime}$ ). By densitometry of the X-ray film we estimated an $\mathrm{H} 1$ recovery rate of approximately $60 \%$.

Ovaries contain, in addition to the oocytes, a large number of somatic tissues such as epithelia and connective tissue. In order to find out whether the positive $\mathrm{H} 1$ signal in the ovary sample was due to the presence of somatic cells, we isolated oocytes of various size classes (stage IV and VI) and carefully removed the follicle epithelium. This was done by a combination of collagenase digestion and manual removal of any follicle remnants still adhering to the oocytes under a dissecting microscope. Proteins solubilized by extraction of 50 oocytes each with PCA were then separated by SDS-PAGE and analyzed for the presence of histone $\mathrm{H} 1$ by immunoblotting. In none of these samples was an $\mathrm{H} 1$ signal detectable (Fig. 1, lanes $5^{\prime}$ and $6^{\prime}$ ). We conclude that histone H1 found in total ovary preparations is derived from somatic cell nuclei and perhaps also from early (stage I and II) oocytes which, due to their small size, could not be isolated sufficiently free of contaminating follicle epithelium.

\section{Somatic Histone H1 Is Not Associated with Lampbrush Chromosomes}

The immunoblots described above were not sensitive enough to clarify the question of whether histone H1 was bound to the lampbrush chromosomes of the oocytes. (A Xenopus oocyte contains $12 \mathrm{pg}$ chromosomal DNA; assuming a DNA/histone mass ratio of 1:1 and a relative amount of $\mathrm{H} 1$ in chromatin of $20 \%$, one oocyte nucleus would contain $2.4 \mathrm{pg}$ chromatin-bound H1. Assuming quantitative recovery, 50 oocytes would yield a total of $120 \mathrm{pg} \mathrm{H} 1$ - an amount which is below the detection limit of our immunoblots; see below.) We therefore used immunofluorescence microscopy. This method was sensitive enough to detect histone $\mathrm{H} 1$ in interphase chromatin and individual mitotic chromosomes of cul- tured Xenopus cells (not shown). Since formaldehyde fixation interfered with the antibody reaction, ovary pieces were fixed by freeze-substitution in either "methacarn" or ethanol prior to paraffin embedding. Identical results were obtained with both modes of freeze-substitution (see also Moorman and de Boer, 1985). Immunofluorescence microscopy using the antiH1 antibodies on paraffin sections of ovary showed strong and specific staining of the nuclei of all somatic cells, in particular those of the follicle epithelium layer surrounding each oocyte (Figs. 2a and 2c). Lampbrush chromosomes were faintly stained only in previtellogenic (Fig. 2a) and not in larger vitellogenic oocytes (Fig. 2c).

Results obtained with isolated lampbrush chromosomes confirmed the in situ data. When chromosomes were prepared from early stage II oocytes before the onset of vitellogenesis, the chromosomal axes fluoresced after incubation with antibodies to H1 (Fig. 2b). In contrast, lampbrush chromosomes isolated from later stage IV-V oocytes did not fluoresce under the same conditions (Fig. 2d). Histone H1 seemed to gradually disappear from the chromosomes during oogenesis since preparations from intermediate stage III oocytes revealed an axial fluorescence that was less intense than that of stage II chromosomes but which was still above background levels (not shown). In control preparations using mAb GA199 the axes of lampbrush chromosomes, independent of the oogenic stage, always fluoresced with equal intensities (Fig. 2e). This finding illustrates that the core histones, in contrast to H1, are integral constituents of lampbrush chromosomes throughout oogenesis.

When probed with anti-B4 antibodies the chromosomes were completely negative both in paraffin sections and after isolation. Amplified nucleoli, however, fluoresced brightly (not shown).

\section{Somatic Histone H1 and the Amplified Nucleoli}

In immunofluorescence experiments the amplified nucleoli of small oocytes reacted strongly with anti-H1 (Figs. 2a and 2b), in agreement with earlier findings of Moorman and de Boer (1985). In spread preparations it was evident that the dumbbell-shaped nucleoli of previtellogenic oocytes fluoresced uniformly (Fig. 2b). Globular nucleoli from more advanced oocytes (stage III) were also homogeneously fluorescing (not shown). During later stages of oogenesis (oocyte stages IV-VI) fluorescence became weaker and restricted to the internal nucleolar component (Fig. 2d). This nucleolar "core" sensu Miller and Beatty (1969) was usually refractory toward the spreading conditions used, unlike the surrounding nucleolar "cortex" material which swelled quite considerably (Fig. $2 \mathrm{e}^{\prime}$ ) or occasionally even completely disap- 
peared (Fig. 2d'). In numerous control experiments we observed a comparable staining of the internal nucleolar component using a number of irrelevant immunoglobulins. Therefore we conclude that the weak fluorescence of the internal component of the amplified nucleoli from oocyte stages IV-VI seen with anti-H1 is due to nonspecific binding of immunoglobulins.

\section{Microinjected Histone H1 Binds to the Lampbrush Chromosomes}

In order to find out whether histone $\mathrm{H} 1$ could be prevented from binding to the lampbrush chromosomes, we injected exogenous $\mathrm{H} 1$ into Xenopus oocytes. Histone H1 extracted with PCA from XLKE-A6 cells was microinjected into the cytoplasm of midsized (stage IV) oocytes. Within $2 \mathrm{hr}$ about half of the injected histone molecules are transported into the germinal vesicle (Dingwall and Allen, 1984). The chromosomes were then isolated and the distribution of $\mathrm{H} 1$ was analyzed by immunofluorescence microscopy. The result clearly demonstrated that microinjected $\mathrm{H} 1$ bound to the central chromomere axis of the lampbrush chromosomes (Fig. 3a). In addition, the amplified nucleoli accumulated $\mathrm{H} 1$ to some extent as indicated by their fluorescence (Fig. 3a). Chromosomes and nucleoli isolated from control oocytes injected with BSA did not react with the anti-H1 antibodies (Fig. 3b).

It is interesting to note that injection of exogenous histone $\mathrm{H} 1$ caused retraction of the lateral loops of the lampbrush chromosomes (Fig. $\left.3 \mathrm{a}^{\prime}\right)$. Loop retraction is a general consequence of the inhibition of polymerase IIdependent transcriptional events (Bona et al., 1981; Scheer, 1986). Although the molecular mechanism of inhibition of transcription is unknown, our results indicate that exogenous $\mathrm{H} 1$ interferes with transcriptional events in the oocyte similar to what has been reported in cultured mammalian cells (Bergmann et al., 1988).

\section{On the Existence of a Somatic Histone H1 Store in Xenopus Eggs}

A batch of 320 eggs was extracted with PCA and the solubilized proteins were resolved by SDS-PAGE and analyzed for the presence of $\mathrm{H} 1$ by immunoblot experiments. No histone H1 could be detected (Fig. 4a, lane $2^{\prime}$ ). In order to quantitate the minimum amount of $\mathrm{H} 1$ detectable in our immunoassay, we added histone $\mathrm{H} 1$ of $\mathrm{XLKE}-\mathrm{A} 6$ cells at increasing concentrations to the egg extract. After immunoblotting with anti-H1, as little as $20 \mathrm{ng}$ histone $\mathrm{H} 1$ was detectable (Fig. 4b, lane 4', arrow). Taking into account a $40 \%$ loss of $\mathrm{H} 1$ during the PCA extraction and subsequent precipitation steps, we conclude that a single Xenopus egg could contain maximally $100 \mathrm{pg}$ histone $\mathrm{H} 1 \mathrm{~A}+\mathrm{B}$, i.e., two orders of magnitude less than the previously reported figure of $8-10 \mathrm{ng} \mathrm{H} 1 \mathrm{~A}$ (van
Dongen et al., 1983). Our results further demonstrate that exogenous $\mathrm{H} 1$ is not degraded to any noticeable extent during the 20 -min incubation in the egg extract.

\section{Chromatin Assembled in Egg Extract Lacks Somatic Histone H1}

Addition of protein-free DNA to Xenopus egg extract induces the assembly of chromatin and nuclear-like structures (e.g., Newport, 1987; Laskey and Leno, 1990). Provided that a maternal store is present in the egg, it is reasonable to assume that histone $\mathrm{H} 1$ should become integrated into the chromatin of the reconstituted nuclei. In fact, Newport (1987) reported the presence of H1 in newly assembled chromatin based on immunofluorescence studies. In our hands, however, nuclei assembled from $\lambda$ DNA were totally negative with antibodies to H1A and H1A/B (Fig. 5a). When we used mAb GA199 as a positive control, the nuclei fluoresced brightly, illustrating the presence of core histones in the reconstituted chromatin (Fig. 5b). Antibodies to B4 protein stained the nuclei slightly above background (not shown). Thus, in contrast to H1, protein B4 appears to be maternally stored and available for the assembly of chromatin. In fact, the existence of a B4 protein pool has been reported in mature oocytes (Smith et al., 1988).

\section{Egg Metaphase II Chromosomes Lack Somatic Histone H1}

Eggs of Xenopus are arrested at the metaphase of the second meiotic cleavage. The highly condensed metaphase II chromosomes are located in a ring-like area close to the animal pole of the egg. Paraffin sections through this region were analyzed by immunofluorescence microscopy. Surprisingly, the chromosomes appeared totally negative with anti-H1 (Fig. 6a). They fluoresced, however, after incubation with mAb GA199, which recognizes $\mathrm{H} 1$ as well as the core histones (Fig. $6 \mathrm{~b})$. Antibodies to B4, a histone-like protein specific for early Xenopus developmental stages (Smith et al., 1988), also produced a strong and specific fluorescence of the metaphase II chromosomes (Fig. 6c).

\section{Appearance of Somatic Histone H1 during Embryogenesis}

In immunoblot experiments with embryos of different developmental stages, histone H1 first became detectable in gastrulae (not shown). Immunofluorescence microscopy confirmed the absence of $\mathrm{H} 1$ in nuclei and mitotic chromosomes of early cleavage stages up to the 64-cell stage (Fig. 7a) but revealed the presence of core histones (Fig. 7b) and B4 protein (Fig. 7c). Thus, the staining pattern of nuclei and chromosomes of early 
ANTIBODIES
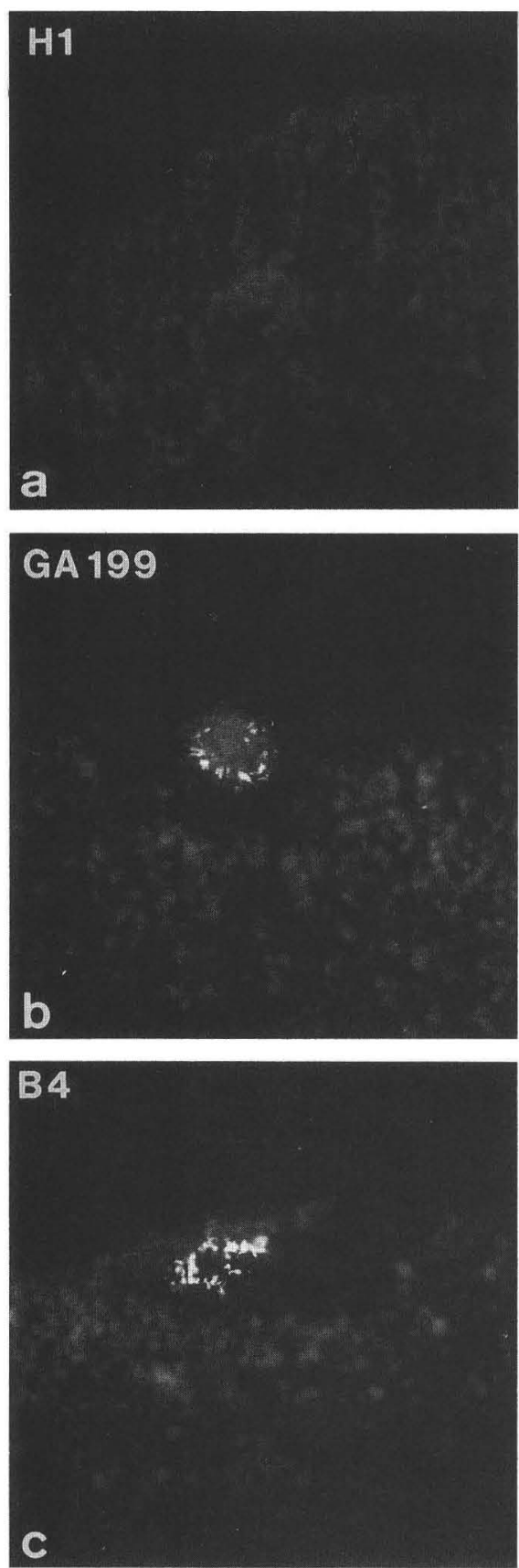

(6)
HOECHST
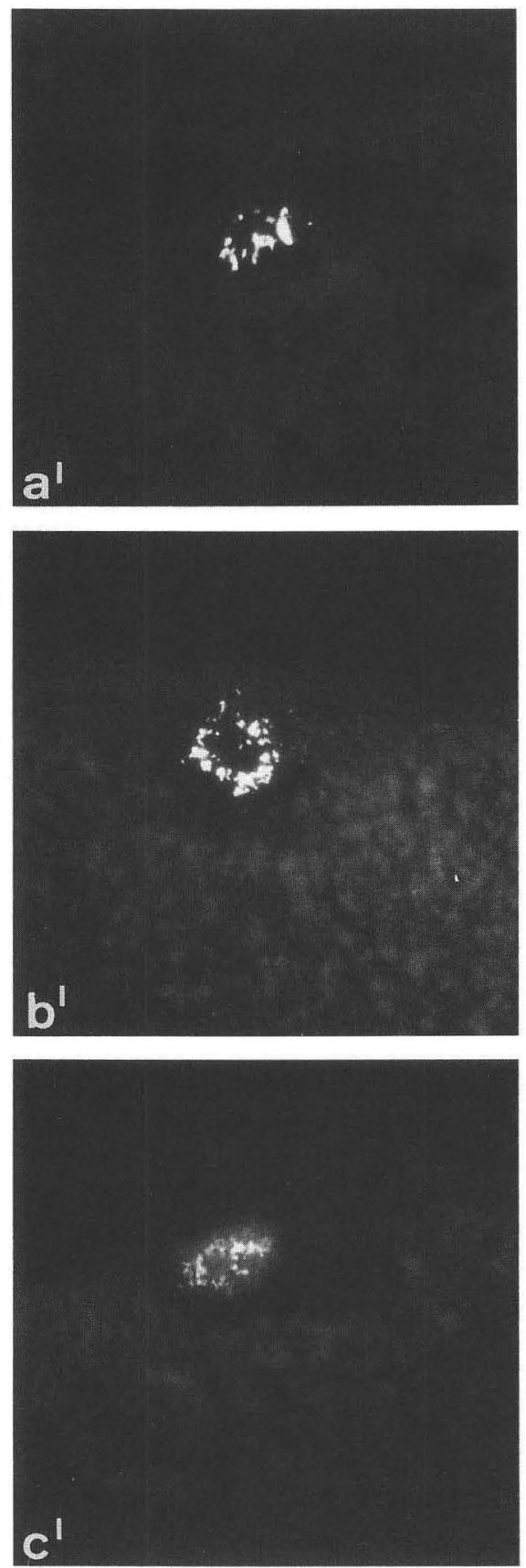

PHASE
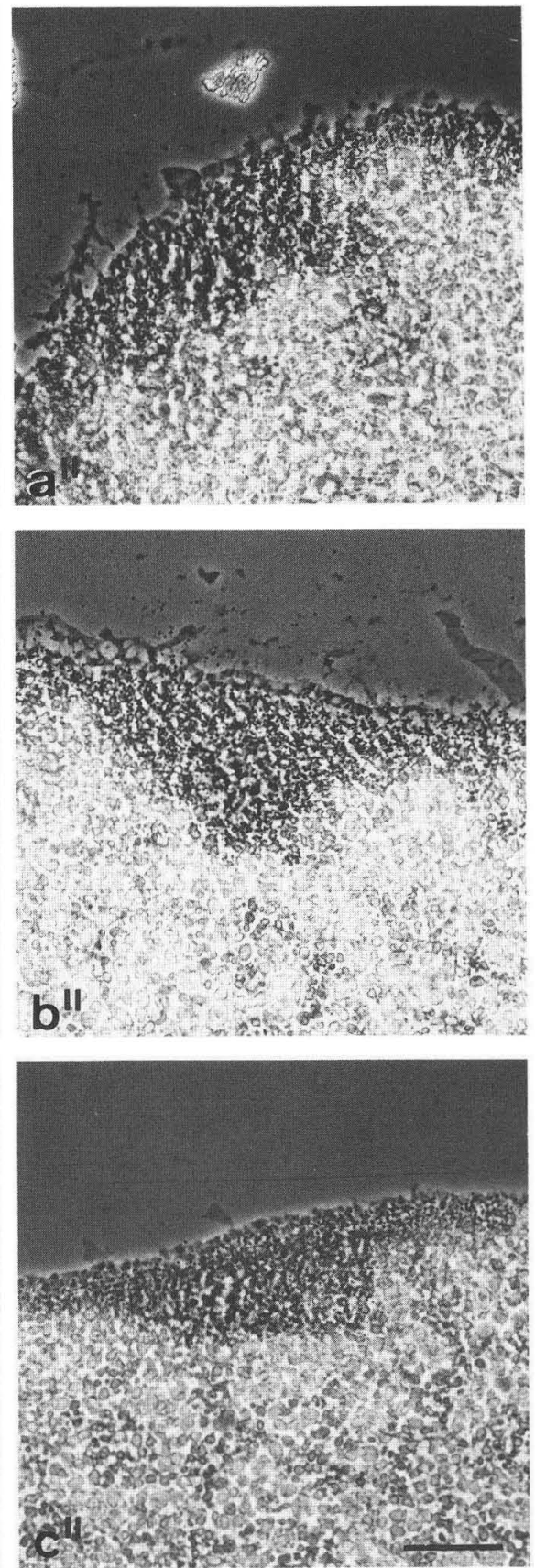

FIG. 6. Immunofluorescence of metaphase II chromosomes in paraffin sections of freeze-substituted Xenopus eggs. Sections were incubated with anti-H1 (a), mAb GA199 directed against H1 as well as the core histones (b), and anti-B4 (c). Counterstaining with Hoechst ( $\left.\mathrm{a}^{\prime}-\mathrm{c}^{\prime}\right)$ and corresponding phase-contrast images $\left(\mathrm{a}^{\prime \prime}-\mathrm{c}^{\prime \prime}\right)$ are shown. In contrast to core histones (b) or the histone H1 variant B4 (c) no H1 is detectable on the metaphase chromosomes (a). Bar, $20 \mu \mathrm{m}$.

cleavage stages obtained with three different antibodies was indistinguishable from that of the egg metaphase II chromosomes (compare Figs. 6 and $7 a-7 c$ ). When the embryos had reached the blastula stage, their chromosomes began to fluoresce after incubation with anti-H1 antibodies (Fig. 7d). In early blastulae, H1 was first de- 
ANTIBODIES
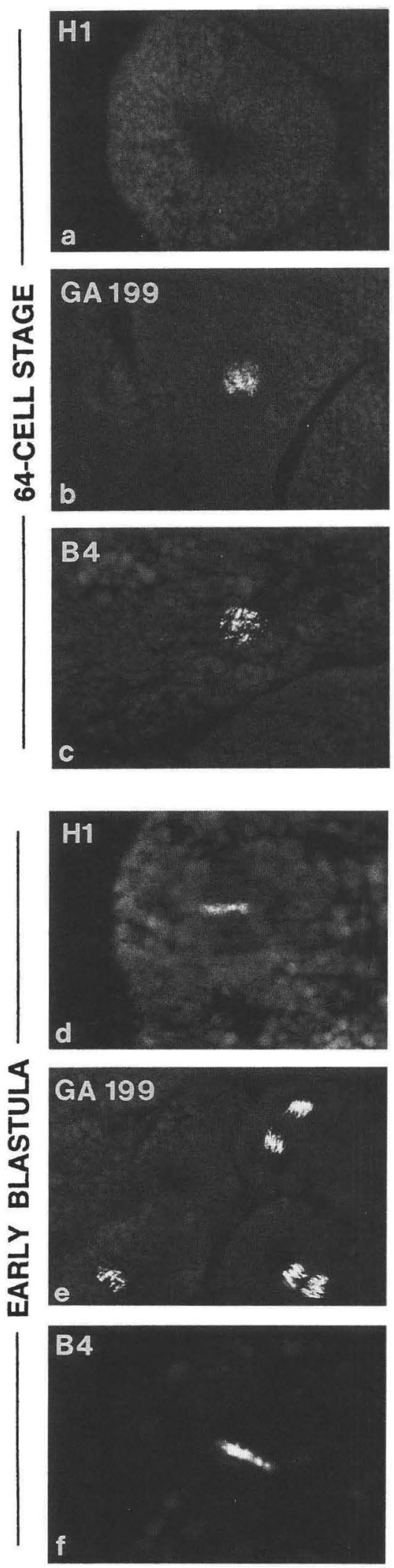

HOECHST
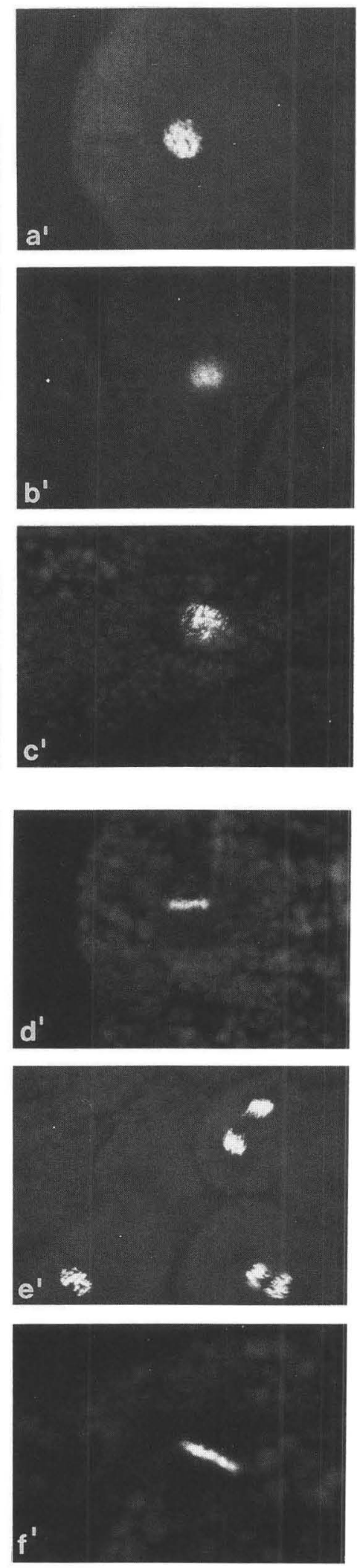

PHASE
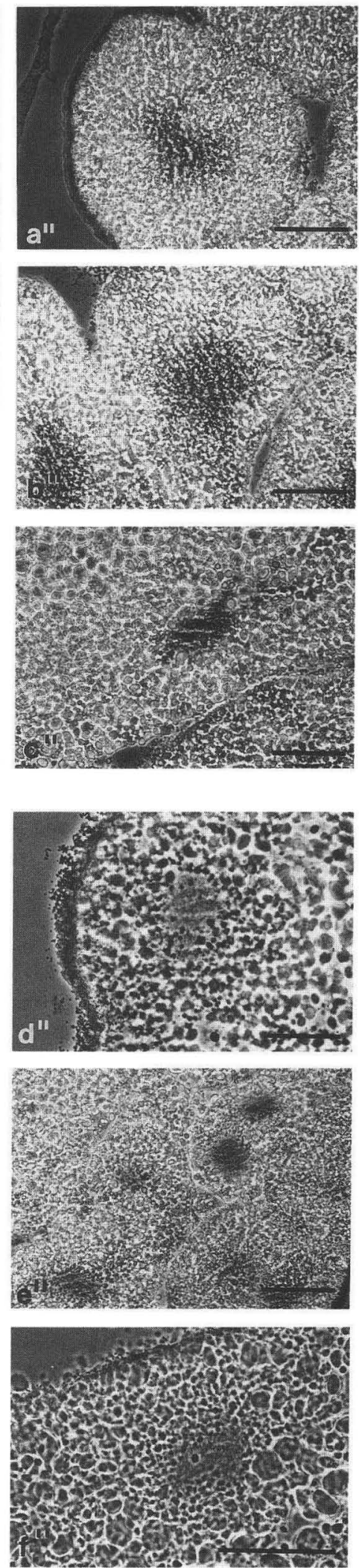

(7)

FIG. 7. Immunofluorescence microscopy of paraffin-sectioned early Xenopus embryos. Sections obtained from a 64-cell stage embryo (a-c) or early blastula (stage 7; d-f) were incubated with the antibodies indicated in the figure. The corresponding DNA-specific Hoechst fluorescence $\left(a^{\prime}-f^{\prime}\right)$ as well as phase-contrast images $\left(a^{\prime \prime}-f^{\prime \prime}\right)$ are shown. Histone H1 is detected in chromosomes of early blastulae (d) but not of preblastula stages (a). The chromosomes are, however, positive for core histones (b,e) and B4 protein (c,f). Bar, $20 \mu \mathrm{m}$. 


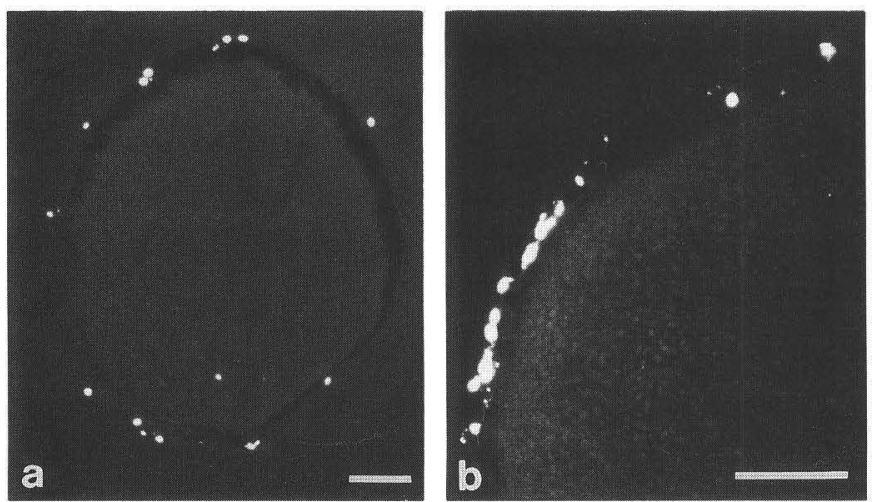

FIG. 8. Adherence of follicle cells to an oocyte isolated by collagenase treatment (a) and to a freshly laid egg (b). Clusters of follicle cells with numerous nuclei are seen at the surface of both the oocyte and the egg as revealed by Hoechst fluorescence of paraffin sections. Bars, $50 \mu \mathrm{m}$.

tectable in association with metaphase chromosomes, whereas the interphase nuclei were hardly stained above background levels. After the midblastula transition and in all subsequent developmental stages $\mathrm{H} 1$ was clearly detectable both in nuclei and chromosomes (not shown).

It is remarkable that in the blastula chromosomes histone $\mathrm{H} 1$ and protein B4 coexisted (Figs. 7d and 7f). Since protein B4 is not detectable in postgastrula embryos (Smith et al., 1988), the blastula and probably also the gastrula stage represent a transition period during which the adult chromatin pattern is gradually established by integration of somatic histone $\mathrm{H} 1$ in and removal of B4 protein from the embryonic chromatin.

\section{DISCUSSION}

Our combined immunoblotting and immunofluorescence analysis described in the present study failed to detect somatic histone $\mathrm{H} 1$ in vitellogenic oocytes, eggs, and preblastula embryos of Xenopus. Histone H1 was first demonstrable by immunofluorescence microscopy in the mitotic chromosomes of blastula embryos and by immunoblotting experiments in gastrula embryos and was present as an ubiquitous chromatin component through subsequent development. Our results confirm and extend biochemical analyses using chromatin assembled in egg or oocyte extract (Dilworth et al., 1987; Shimamura et al., 1988) or isolated from early cleavagestage embryos (Wolffe, 1989; Ohsumi and Katagiri, 1991). They lend further support to the view that a major change in chromatin composition takes place during the blastula stage when the adult histone $\mathrm{H} 1$ pattern is being established (for review see Wolffe, 1991), but speak against the presence of a maternal store of histone $\mathrm{H} 1$.

\section{A Maternal Pool of Somatic Histone H1?}

In a previous study van Dongen et al. (1983) measured 8-10 ng histone H1A per Xenopus oocyte by using semiquantitative immunoblots. Taking into account the limit of detection of our immunoblot procedure, we calculate a maximally possible histone $\mathrm{H} 1 \mathrm{pool}$ of $100 \mathrm{pg}$ per full-grown oocyte or egg. In order to find the reason for the discrepancy of both data we have cytologically examined oocytes prepared from ovaries as described previously (van Dongen et al., 1983). After their separation by collagenase treatment oocytes were embedded in paraffin and sections were analyzed by Hoechst staining. Most of the oocytes were still surrounded by a single-layer follicle epithelium with numerous fluorescing nuclei (Fig. 8a). Therefore we think that the "oocyte" histone H1 described earlier (van Dongen et al., 1983) was derived from contaminating follicle cell nuclei rather than the oocytes proper. The finding that oocytes synthesize $\mathrm{H} 1$ at a low rate (Flynn and Woodland, 1980) might also be explained by the presence of contaminating follicle cells. In the present study we therefore took care to mechanically remove, following the collagenase

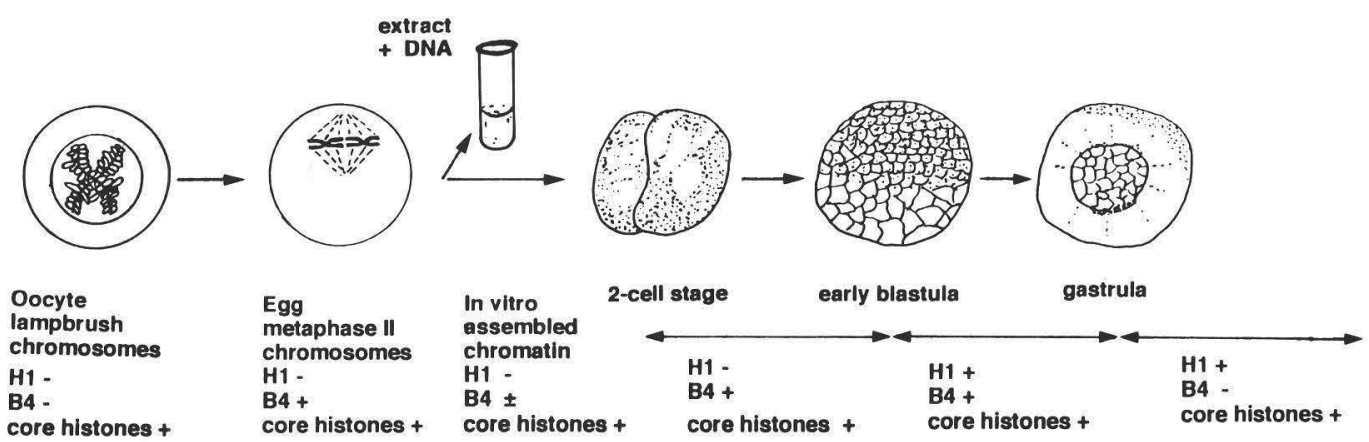

FIG. 9. Diagram summarizing the developmental changes of chromatin composition during later periods of oogenesis and early embryogenesis of Xenopus. Data on the B4 protein were partially taken from Smith et al. (1988). 
treatment, any follicle layers from the oocytes prior to histone analyses.

When we examined freshly laid eggs by Hoechst fluorescence we noted, quite to our surprise, that remnants of somatic tissue frequently adhered to the egg surface (Fig. 8b). Therefore, reports of H1 synthesis by eggs and early cleavage embryos (e.g., Flynn and Woodland, 1980) might also be due to the synthetic activity of contaminating somatic cells.

Thus, although our immunoblot data formally cannot exclude a histone $\mathrm{H} 1$ pool smaller than approximately $100 \mathrm{pg}$ per egg, all available evidence speaks against the occurrence of maternally stored histone $\mathrm{H} 1$.

\section{Absence of Somatic Histone H1 in Lampbrush Chromosomes, Egg Metaphase II Chromosomes, and Preblastula Chromatin}

Although the central chromomere axis of lampbrush chromosomes contains chromatin in a highly condensed form (Scheer, 1987; for review see Callan, 1986), no histone $\mathrm{H} 1$ was detectable. Using paraffin sections through oocytes Moorman and de Boer (1985) also failed to detect chromosome-bound $\mathrm{H} 1$. We can rule out the possibility that a specific feature of the chromosome axis prevented immunological detection. First, when we injected histone $\mathrm{H} 1$ into oocytes, binding of the exogenous $\mathrm{H} 1$ to the chromosome axis was readily visualized by immunofluorescence microscopy. The general accessibility of the lampbrush chromosome axis to antibodies was further documented by their fluorescence in control preparations after incubation with the anti-histone antibody mAb GA199.

It is tempting to speculate that the absence of somatic histone $\mathrm{H} 1$ as well as the $\mathrm{H} 1$-like protein $\mathrm{B} 4$ from lampbrush chromosomes might be causally related to the unraveling of parts of their axial chromatin into numerous lateral loops which are transcriptionally extremely active (for current concepts of lampbrush chromosome organization see Callan, 1986). Isolated lampbrush chromosomes of newt oocytes also lack histone H1 (DiMario et al., 1989). However, such an interpretation contrasts with our finding that $\mathrm{H} 1$ appears to be associated with lampbrush chromosomes of young previtellogenic oocytes (see also DiMario et al., 1989). Thus, at the moment the functional significance of the absence of somatic histone $\mathrm{H} 1$ from lampbrush chromosomes of vitellogenic oocytes remains obscure.

The highly condensed metaphase II chromosomes of eggs as well as the mitotic chromosomes and interphase chromatin of cleavage-stage embryos were also deficient in histone $\mathrm{H} 1$ up to the early blastula stage. However, when the chromosomes of oocytes, eggs, and preblastula embryos were probed with antibodies to the histone H1-like B4 protein, we noted considerable differences in fluorescence patterns. Oocyte lampbrush chromosomes were totally negative, unlike the chromosomes of eggs and early embryos which fluoresced brightly. This differential staining of the chromosomes is surprising in view of the constant levels of stored B4 protein reported in oocytes, eggs, and early embryos (Smith et al., 1988). Thus, in the oocyte the B4 protein must be somehow prevented from binding to the lampbrush chromosomes, possibly by storage in the amplified nucleoli, as suggested by their strong fluorescence with anti-B4 antibodies.

\section{Developmental Regulation of Histone H1 Expression in Xenopus}

Our results together with those reported by others allow us to describe developmentally regulated changes in histone $\mathrm{H} 1$ composition of chromatin during oogenesis and early embryogenesis of Xenopus (summarized in Fig. 9). Lampbrush chromosomes of vitellogenic oocytes, metaphase II chromosomes of eggs, and chromosomes/chromatin of preblastula embryos are all devoid of somatic histone $\mathrm{H} 1$. The absence of $\mathrm{H} 1$ subtypes characteristic of differentiated cells seems to be a common feature of oocytes and early embryos of a variety of species (reviewed by Poccia, 1986) including Drosophila (Frasch, 1985) and mouse (Clarke et al., 1992). However, the situation in Xenopus appears to be even more complex since lampbrush chromosomes of small previtellogenic oocytes react positively with anti-H1. At the moment we do not know whether H1 associated with early lampbrush chromosomes is inherited from chromatin of pre-diplotene oocytes or synthesized transiently during early periods of oogenesis. Future studies will have to clarify whether the loss of somatic histone $\mathrm{H} 1$ from the lampbrush chromosomes around the onset of vitellogenesis is compensated for by an as yet unknown oocyte-specific histone $\mathrm{H} 1$ subtype. The negative outcome of our immunofluorescence studies with anti-B4 antibodies at least shows that B4, an H1-like protein (Smith et al., 1988), is not a component of the lampbrush chromosomes.

Metaphase II chromosomes of eggs and chromatin of preblastula embryos are deficient in histone $\mathrm{H} 1$ but contain protein $\mathrm{B} 4$ which might functionally replace somatic histone H1 during early cleavage stages (cf. Smith et al., 1988). Biochemical analyses of cleavage-stage chromatin have also revealed the absence of somatic histone $\mathrm{H} 1$ and the presence of a H1-related protein termed H1X that might be identical to the B4 protein (Wolffe, 1989; Ohsumi and Katagiri, 1991). In the subsequent blastula stage the $\mathrm{B} 4$ protein and somatic histone $\mathrm{H} 1$ coexist in chromatin. Once H1 appears it remains 
present in all somatic cell nuclei throughout development up to the adult stage. In contrast, the B4 protein is no longer detectable in postgastrula stages (Smith et al., 1988).

We noted the first appearance of somatic $\mathrm{H} 1$ at the early blastula stage, i.e., prior to the midblastula transition. This observation supports the concept that $\mathrm{H} 1$ is initially synthesized by mobilization of maternally stored transcripts (Woodland, 1980). It is interesting to note that the developmental period at which the embryonic chromatin adopts the adult pattern coincides with repression of the oocyte-type 5S RNA genes and satellite I DNA (Wolffe, 1989, 1991).

We thank Dr. M. Birnstiel and Dr. E. Dworkin-Rastl for their gift of anti-B4 antiserum and Hilde Merkert for skillful technical assistance. This work received financial support from the Deutsche Forschungsgemeinschaft (Grant Sche 157/9-1).

\section{REFERENCES}

Bergman, M. G., Wawra, E., and Winge, M. (1988). Chicken histone H5 inhibits transcription and replication when introduced into proliferating cells by microinjection. J. Cell Sci. 91, 201-209.

Bona, M., Scheer, U., and Bautz, K. F. (1981). Antibodies to RNA polymerase II (B) inhibit transcription in lampbrush chromosomes after microinjection into living amphibian oocytes. J. Mol. Biol. 151, 81-99.

Callan, H. G. (1986). "Lampbrush Chromosomes.” Springer-Verlag, Berlin/New York.

Clarke, H. J., Oblin, C., and Bustin, M. (1992). Developmental regulation of chromatin composition during mouse embryogenesis: Somatic histone $\mathrm{H} 1$ is first detectable at the 4-cell stage. Development 115, 791-799.

Dabauvalle, M.-C., Loos, K., Merkert, H., and Scheer, U. (1991). Spontaneous assembly of pore complex-containing membranes ("annulate lamellae") in Xenopus egg extract in the absence of chromatin. $J$. Cell Biol. 112, 1073-1082.

Davidson, E. H. (1986). "Gene Activity in Early Development." Academic Press, Orlando.

Destrée, O. H. J., d'Adelhart Toorop, H. A., and Charles, R. (1973). Analysis of histones from different tissues and embryos of Xenopus laevis. II. Qualitative and quantitative aspects of nuclear histones during early stages of development. Cell Differ. 2, 229-242.

Dilworth, S. M., Black, S. J., and Laskey, R. A. (1987). Two complexes that contain histones are required for nucleosome assembly in vitro: Role of nucleoplasmin and N1 in Xenopus egg extracts. Cell 51, 10091118.

Dilworth, S. M., and Dingwall, C. (1988). Chromatin assembly in vitro and in vivo. BioEssays 9, 44-49.

DiMario, P. J., Bromley, S. E., and Gall, J. G. (1989). DNA-binding proteins on lampbrush chromosome loops. Chromosoma 97, 413-420.

Dingwall, C., and Allan, J. (1984). Accumulation of the isolated carboxy terminal domain of histone $\mathrm{H} 1$ in the Xenopus oocyte nucleus. EMBO J. 3, 1933-1937.

Dumont, J. N. (1972). Oogenesis of Xenopus laevis (Daudin). J. Morphol. 136, 153-180.

Flynn, J. M., and Woodland, H. R. (1980). The synthesis of histone H1 during early amphibian development. Dev. Biol. 75, 222-230.

Frasch, M. (1985). Charakterisierung chromatinassoziierter Kernpro- teine von Drosophila melanogaster mit Hilfe monoklonaler Antikörper. Ph.D. thesis, University of Tübingen, Germany.

Gall, J. G., Stephenson, E. C., Erba, H. P., Diaz, M. O., and BarsacchiPilone, G. (1981). Histone genes are located at the sphere loci of newt lampbrush chromosomes. Chromosoma 84, 159-171.

Krohne, G., Dabauvalle, M.-C., and Franke, W. W. (1981). Cell-type specific differences in protein composition of nuclear pore complexlamina structures in oocytes and erythrocytes of Xenopus laevis. $J$. Mol. Biol. 151, 121-141.

Kyhse-Andersen, J. (1984). Electroblotting of multiple gels; a simple apparatus without buffer tank for rapid transfer of proteins from polyacrylamide to nitrocellulose. J. Biochem. Biophys. Methods 10, 203-209.

Laemmli, U. K. (1970). Cleavage of structural proteins during the assembly of the head of bacteriophage T4. Nature 227, 680-685.

Laskey, R. A., and Leno, G. H. (1990). Assembly of the cell nucleus. Trends Genet. 6, 406-409.

Laybourn, P. J., and Kadonaga, J. T. (1991). Role of nucleosomal cores and histone $\mathrm{H} 1$ in regulation of transcription by RNA polymerase II. Science 254, 238-245.

Miller, O. L., and Beatty, B. R. (1969). Visualization of nucleolar genes. Science 164, 955-957.

Moorman, A. F. M., de Boer, P. A. J., Linders, M. Th., and Charles, R. (1984). The histone H5 variant in Xenopus laevis. Cell Differ. 14, 113-123.

Moorman, A. F. M., and de Boer, P. A. J. (1985). Immunohistochemical distribution of the histone $\mathrm{H} 1^{\circ} / \mathrm{H} 5$ variant in various tissues of adult Xenopus laevis. Cell Differ. 16, 109-117.

Newmeyer, D. D., Lucocq, J. M., Bürglin, T. R., and DeRobertis, E. M. (1986). Assembly in vitro of nuclei active in nuclear protein transport: ATP is required for nucleoplasmin accumulation. EMBO J. 5, 501-510.

Newport, J. (1987). Nuclear reconstitution in vitro: Stages of assembly around protein-free DNA. Cell 48, 205-217.

Nicolas, R. H., and Goodwin, G. H. (1982). Isolation and analysis. In “The HMG Chromosomal Proteins" (E. W. Johns, Ed.), pp. 42-67. Academic Press, London.

Nieuwkoop, P. D., and Faber, J. (1975). "Normal Table of Xenopus laevis (Daudin)." North-Holland, Amsterdam.

Ohsumi, K., and Katagiri, C. (1991). Occurrence of H1 subtypes specific to pronuclei and cleavage stage cell nuclei of anuran amphibians. Dev. Biol. 147, 110-120.

Peng, H. B. (1991). Solutions and protocols. In "Methods in Cell Biology” (K. B. Kay and H. B. Peng, Eds.), Vol. 36, pp. 657-662. Academic Press, London.

Platz, S. (1991). Immunologische und biochemische Charakterisierung eines Histon erkennenden Antikörpers. Diploma Thesis, University of Würzburg, Germany.

Poccia, D. (1986). Remodeling of nucleoproteins during gametogenesis, fertilization, and early development. Int. Rev. Cytol. 105, 1-65.

Renz, M., Nehls, P., and Hozier, J. (1977). Involvement of histone H1 in the organization of the chromosome fiber. Proc. Natl. Acad. Sci. USA 74, 1879-1884.

Risley, R. S., and Eckhardt, R. A. (1981). H1 histone variants in Xenopus laevis. Dev. Biol. 84, 79-87.

Rodriguez-Campos, A., Shimamura, A., and Worcel, A. (1989). Assembly and properties of chromatin containing histone H1. J. Mol. Biol. 209, 135-150.

Scheer, U. (1986). Injection of antibodies into the nucleus of amphibian oocytes: An experimental means of interfering with gene expression in the living cell. J. Embryol. Exp. Morphol. 97, 223-243.

Scheer, U. (1987). Structure of lampbrush chromosome loops during different states of transcriptional activity as visualized in the presence of physiological salt concentrations. Biol. Cell 59, 33-42. 
Scheer, U., and Dabauvalle, M.-C. (1985). Functional organization of the oocyte nucleus. In "Developmental Biology" (L. W. Browder, Ed.), Vol. 1, pp. 385-430. Plenum, New York.

Shimamura, A., Tremethick, D., and Worcel, A. (1988). Characterization of the repressed 5S DNA minichromosomes assembled in vitro with a high speed supernatant of Xenopus laevis oocytes. Mol. Cell. Biol. 8, 4257-4269.

Shimamura, A., Sapp, M., Rodriguez-Campos, A., and Worcel, A. (1989). Histone $\mathrm{H} 1$ represses transcription from minichromosomes assembled in vitro. Mol. Cell. Biol. 9, 5573-5584.

Schlissel, M. S., and Brown, D. D. (1984). The transcriptional regulation of Xenopus 5S RNA genes in chromatin: The roles of active stable transcription complexes and histone H1. Cell 37, 903-913.

Smith, R. C., Dworkin-Rastl, E., and Dworkin, M. B. (1988). Expression of a histone H1-like protein is restricted to early Xenopus development. Genes Dev. 2, 1284-1295.

Smith, J. C., and Tata, J. R. (1991). Xenopus cell lines. In "Methods in Cell Biology" (K. B. Kay and H. B. Peng, Eds.), Vol. 36, pp. 635-654 Academic Press, London.

Thoma, F., Koller, T., and Klug, A. (1979). Involvement of histone H1 in the organization of the nucleosome and of the salt dependent superstructure of chromatin. J. Cell Biol. 83, 403-427.

van Dongen, W. M. A. M., Moorman, A. F. M., and Destrée, O. H. J. (1983). The accumulation of the maternal pool of histone H1A during oogenesis in Xenopus laevis. Cell Differ. 12, 257-264.

van Holde, K. E. (1989). "Chromatin." Springer-Verlag, New York/ Berlin.

Wolf, D. P., and Hedrik, J. L. (1971). A molecular approach to fertilization. II. Viability and artificial fertilization of Xenopus laevis gametes. Dev. Biol. 25, 348-359.

Wolffe, A. P. (1989). Dominant and specific repression of Xenopus oocyte 5S RNA genes and satellite I DNA by histone H1. EMBO J. 8, 527-537.

Wolffe, A. P. (1991). Developmental regulation of chromatin structure and function. Trends Cell Biol. 1, 61-66.

Woodland, H. R., and Adamson, E. D. (1977). The synthesis and storage of histones during oogenesis of Xenopus laevis. Dev. Biol. 57, 118-135.

Woodland, H. R. (1980). Histone synthesis during the development of Xenopus. FEBS Lett. 121, 1-7. 